\title{
Redefining Cablaka "Banyumasan Way of Speaking": Is It Totally Explicature?
}

\author{
Chusni Hadiati \\ English Language and Literature Study Program, Department of Humanities, Faculty of Social and Political Sciences, \\ Jenderal Soedirman University, Purwokerto, Central Java, Indonesia
}

\begin{abstract}
Banyumasan is a dialect of Javanese language. It is mainly spoken along the flow of Serayu river. Language as it is used in a speech community can reflect the community itself and so does Banyumasan. Banyumasan which has different linguistic feature compared to its standard Javanese also reflects the way of speaking of its speaker. The way of speaking in Banyumas is commonly known as Cablaka. Cablaka is Banyumasan way of speaking which means that a speaker tend to speak frankly based on the actual fact. However the phenomena shows us different thing. People, sometimes inevitably speak indirectly. Speakers express their thought to their hearers implicitly. What is meant without being said is generally called implicature. On the other hand, explicature happens when what is meant is as what is said. This article intends to redefine the concept of Cablaka as Banyumas way of speaking in the context of traditional selling and buying in Banyumasan. The implicatures found in selling and buying transaction are disagreeing, promising, commanding, requesting, accusing, keeping a secret and forbidding. The functions of implicatures in selling and buying transaction are to show politeness, to show respect, to show carefulness, to show uncertainty, and to keep face.
\end{abstract}

Index Terms — cablaka, traditional selling and buying, implicature, explicature

\section{INTRODUCTION}

Javanese language is grouped into Proto Austronesian language. Wedhawati et al (2006) states that "Proto Austronesian is divided into two groups: west and east. The west proto austronesian consists of: Malay language, Sundanese, Javanese, Balinese, Maduranese, Bugis, and languages in North Sulawesi and Philippines archipelago"(p.6). Ogloblin (2005) elaborates that the Javanese form the largest community in the Austronesian language family (p. 590). With about 80 million people at the end of the twentieth century, they make up about $40 \%$ of the Indonesian population.

Javanese has some dialects, one of them is Banyumasan. Banyumasan is said as the dialect of standard Javanese. Standard Javanese is mainly spoken in Yogyakarta and Surakarta. Compared to standard Javanese spoken in Yogjakarta, Surakarta, Banyumasan has some different features. Those differences are due to phonological dan lexical features.

Language as a means of communication may vary from one place to another. The variation is causes by some factors, such as geographical barrier and social factors. Chambers and Trudgill $(1994$, p.3) states that the variation caused by geographical barrier is also known as dialect.

Banyumasan is a dialect used along the flow of Serayu River. The river flows from Sindoro-Sumbing Mountains (Koentjaraningrat, 1984, p.23). The way people speak in this dialect is called Cablaka. Cablaka in a simple way can be defined as the way to speak frankly based on the fact. Cablaka is more responsible than Blakasuta since people speak directly based on the fact. On the other hand, Blakasuta is saying something without considering anything. Blakasuta is less responsible than Cablaka (Herusatoto, 2008, p.124). However, the fact show us something different The way people speak in traditional selling and buying in Banyumasan does not always reflect Cablaka. Both buyers and sellers sometimes express their thought indirectly. This indirect saying in linguistic is widely known as implicature. People use implicature in traditional selling and buying in Banyumas. If Cablaka is really the way of speaking in Banyumasan, it can be simplified that people use explicature as it is opposed to implicature. Thus, this article tries to investigate the implicature in traditional selling and buying in Banyumasan as a foundation to redefine the term Cablaka as the way of speaking of Banyumas people. The investigation to redefine Cablaka is traced by using linguistic evidence that is conversational implicature which takes place in the conversation of traditional selling and buying transaction.

Basically language used as a means of communication is divided into two forms; spoken and written. Each of them has some characteristics which differentiate one from another. Spontaneous speech is unlike written text. It contains many mistakes, sentences are usually brief and indeed the whole fabric of verbal expression is riddled with hesitation and silences (Halliday, 1994, p.76). He also mentions that provided whatever criteria are adopted are applied consistently, the lexical density of written language is likely to be of the order of twice as high as that for speech; and the discrepancy will be greater if other factors such as the relative probability of lexical items are taken into account (p. 80)

However, in delivering message, spoken language is also as informative as written language. Spoken language also has both surface and deep structure. Halliday (1994) quotes that speech is, by its nature, 'low in content'-in the special 
sense of lexical density...; but it is not 'low in content' in the general sense of lacking information; and it is certainly not unstructured and superficial (p. 77). The statement that spoken language is not unstructured and superficial implies that spoken language also has surface and deep structure.

Selling and buying things is very close to human social life. In doing so, language plays an important role. The conversation happened in selling and buying is an interesting language phenomenon in our society. This type of conversation cannot be classified as casual conversation since casual conversation does not have any clear pragmatic purposes (Eggins and Slade, 1997). The conversation in selling and buying things has a clear pragmatic purposes, that is one participant gets things or services the other participant provides things or services.

No matter how simple a text is, it always has a structure. It is in line with Ventola (1979) who states that 'even in the use of language that appears most effortless and least specialized, namely casual conversation possesses structure in this sense. Structure is made up of separate events or elements. Hasan (1989) mentions the obligatory elements of selling and buying text as follows: sale request, sale compliance, sale, purchase, purchase closure. The generic structure of selling and buying text consists of sale initiation, sale request, sale compliance, sale inquiry, sale, purchase, purchase closure, finis. From her definition, it can be summed up that sale initiation, sale inquiry, finis are the optional elements.

The use of language in selling and buying can be categorized into three major functions. The first is referential function which means that language is used as a means to transaction of good and services. The second is emotive function. Language is used to express speakers' feeling and thought. People go to markets or traditional kiosk not only for buying good but sometimes they go there just for chatting. The third function is informative function. This means that language is used by both seller and buyer to gain information about the good and any other thing. Halliday (1989) explains that context is divided into three concepts. These concepts serve to interpret the social context of a text, the environment in which meanings are being exchanged (p.12). The first is field of discourse. Field of discourse refers to what is happening, to the nature of the social action that is taking place: what is it that the participants are engaged in, in which the language figures as some essential components. The second is tenor of discourse. Tenor of discourse refers to who is taking part, to the nature of the participants, their statutes and roles: what kind of role-relationship obtain among the participants, including permanent and temporary relationship of one kind or another, both the type of speech role that they are taking on in the dialogue and the whole cluster of socially significant relationships in which they are involved. The third is mode of discourse. Mode of discourse refers to what part of language is playing, what it is that the participants are expecting the language to do for them in that situation: the symbolic organization of the text, the status that it has, and its function in the context, including the channel (is it spoken or written or some combination of the two) and also the rhetorical mode, what is being achieved by the text in terms of such categories as persuasive, expository, didactic, and the like.

Speech acts are words that do things (Mey, 1994, p.110). When an utterance is produced it is not merely a combination of words. It has deeper intention. When one says 'I'll come tomorrow' he does not solely say it, however; at the same time when he produces this utterance he also makes a promise. Words that functions as 'promise' means that they do 'something'. Searle (1969) in Mey (1994, p. 165-167) classifies speech acts into five categories, as follows: representatives, directives, commissives, expressives, and declaration.

In order to be an effective communicator, a speaker and a hearer have to obey the cooperative principle proposed by Grice. He mentions that each speaker should give 'enough' contribution in conversation. He divides the cooperative principles into four maxims (Levinson, 1983, p. 101-102). The first is maxim of quality. This maxim contains an advice for the speakers to make their contribution one that is true, specifically; do not say what you believe to be false and do not say that for which you lack adequate evidence. The second is maxim of quantity. It includes the suggestion for the speakers to make their contribution as informative as is required for the current purposes of the exchange and do not make contribution more informative than is required. The third is maxim of relevance. It involves the recommendation for the speakers to make their contribution relevant. Last but not least is maxim of manner. It consists of advice for the speakers to be perspicuous and specifically avoid obscurity, avoid ambiguity, be brief, and be orderly.

The four maxim of Grice's cooperative principles are then simplified by Sperber and Wilson (1986) into one principle that is relevance principle. It then triggered the emergence of relevance theory. Communication is a process involving two information-processing devices. One device modifies the physical environment of the other. As a result, the second device constructs representations similar to representations similar already stored in the first devices. Oral communication, for instance, is a modification by the speaker of the hearer's acoustic environment, as a result of which the hearer entertains thoughts similar to the speaker's own. Whether an utterance is relevance or not can be explained by using the contextual assumptions. Those assumptions will inevitably lead the participants to make contextual implications. Sperber and Wilson specifically highlighted that communication is a matter of enlarging mutual cognitive environment, not to duplicating thoughts. The most important differences between Grice's approach and relevance theory has to do with the explanation of communication. Grice's account of conversations starts from a distinction between what is explicitly said and what is implicated. No explanation of explicit communication is given; essentially, the code model, with a code understood as a set of conventions, is assumed to apply. Implicatures are explained as assumptions that the audience must make to preserve the idea that the speaker has obeyed the maxims, or at least the cooperative principle. The principle of relevance is intended to explain ostensive communication as whole, both explicit and implicit. 
Cablaka is the tendency to speak frankly; it is widely recognized in linguistics as explicature. Sperber and Wilson (1986) mention that the assumption communicated by speaker fall into two classes: explicature and implicature(p. 182). An assumption communicated by an utterance $U$ is explicit [hence an 'explicature'] if and only if it is a development of a logical form encodes by U. An assumption communicated by $U$ which is not explicit is implicit [hence an implicature']

Carston (2002) mentions that there are two point worth emphasizing in explicature (p. 116). The first is that the explicature/implicature distinction applies only to those assumptions that fall within the speaker's communicative intention. This leads to the the possibility of a difference between the proposition expressed by the speaker and her explicature (s): the proposition expressed may or may not be communicated; only when it is communicated is it an explicature of the utterance. The second is that it is clearly the content of explicature comes from two distinct sources, the linguistic expression used and the context, and it is derived in two distinct ways depending on its source, by linguistic decoding or by pragmatic inference.

Implicature can be resulted from the flouting of maxim of the cooperative principles. When a speaker exploits those maxims, he or she tries to hide something. The 'hidden' thing is the implied meaning of the conversation, Therefore this implied meaning is the conversational implicature.

Conversational implicature is a proposition which is probably implied or meant by the speaker which may be different from what he or she actually said in a conversation (Grice, 1975, p. 43). Mey (1994) adds that a conversational implicature is, therefore, something which is implied in conversation, that is, something which is left implicit in actual language use. In brief, it can be said that conversational implicture is something left unsaid by the participants of the conversation.

\section{Methodology}

This research is a descriptive qualitative research since, the researcher describes the data qualitatively. Cresswell (1994) mentions that a qualitative research is an exploratory research where the researcher explores a single entity or phenomenon (the case) bounded by time and activity and collects detailed information by using a variety of data collection procedures during a sustained period of time. Data are derived from natural conversation happened in buying and selling in Banyumasan dialect. Hammersley (1992) highlighted that natural occurring data is preferable in qualitative research. Data was taken from traditional selling and buying conversation in both traditional markets and kiosks in Banyumas regency, Cilacap regency, Banjarnegara regency, Purbalingga regency, Kebumen regency. Banyumasan dialect is used in those regencies. Conversation is recorded by using tape recorder or handy-cam secretly. Data is then analyzed by using the relevance theory and context to find the conversational implicatures. Those implicatures are then classified into Searle's speech acts. By proving that implicature really happens in this conversation, the researcher then redefines Cablaka.

\section{RESULT AND DISCUSSION}

The analysis shows that indirectness is used to show politeness, to show respect, to soften utterance, to show carefulness, to show uncertainty and to keep face. By using the function of indirectness in Banyumasan, this article tries to redefine cablaka.

This article tries to reveal the phenomenon of implicature in Banyumasan as the base to redefine Cablaka, the discussion starts with implicature in traditional selling and buying in Banyumasan.

The first conversation depicts the implicature of disagreement. The second utterance of below conversation shows that the speaker does not agree with the first utterance.

Context: The celebration of Independence Day happened during fasting month. Many festivals and celebrations were held on July not in August. July is a dry session which means the production of coconut sugar touched its lowest point. One of coconut sugar producer is selling his coconut sugar in the shop. While waiting for his turn, he watched the march from the shop.

Utterance 1: Rame semanger ya, pitulasan nang kota rame samayar ya pitulasan nay kota It's merry here, Independence Day in town

Utterance 2: Ya rame lah.... Rame nang bocah

Ya rame lah rame nay bocah

Yes it's merry.... Merry by children...

Utterance 1 is produced by a coconut sugar seller. Utterance 2 is made by shop owner husband. The conversational implicature of the above conversation is disagreement. At first, utterance 2 shows that the speaker agrees with utterance 1. By saying ya rame lah... He agrees upon the first utterance that the Independence Day celebration in town is merry. However, when he adds other premise, Rame nang bocah he denies what he agrees upon. He thinks that Independence Day celebration is only merry by children not by coconut sellers. There are some contextual assumptions that can be made from the utterance Rame nang bocah.

1. It is July and dry session, so that the production of palm sugar reduce drastically. 
2. Due to the reduction, the amount of palm sugar sold is also reduced and it will automatically reduce the shop owner income.

3. The income reduction is not a pleasant thing for the shop owner husband. Moreover, as the shop owner, he has to prepare some present for his coconut sugar seller.

4. It can be assumed that if it is merry with children, only children (or most of the children) who celebrated the Independence Day. Children will not purchase more money on coconut sugar hence the shop owner cannot make more money. From the contextual assumptions mentioned above, it can be concluded that the shop owner utterance Rame nang bocah implies that he does not mean to say that the Independence Day is really merry. So his utterance is meant to show his disagreement. Based on Searle's classification, disagreement is classified into representative.

If the shop owner husband says directly that he does not agree with the first utterance, he can simply say it. In fact, he says it indirectly. This shows that he does not reflect Cablaka in his utterance since he does not say it explicitly. The shop owner husband tries to be polite to his interlocutor by showing his disagreement indirectly. His indirectness is aimed to give information and to maintain politeness to his interlocutor simultaneously. The shop owner husband wants to inform his hearer that the celebration of the Independence Day is not really merry which means that he disagrees with his interlocutor first statement. He also wants to show politeness to his interlocutor since he know that he has business with his interlocutor so that if he cannot maintain a good social relationship by showing politeness he may lose one of his potential business partners.

The second conversation below shows the indirectness which takes place in traditional selling and buying in Banyumasan dialect. The conversation occurs during the fasting month.

Context: During the fasting month, the demand for eggs rises. Hence the shop owner sometimes forgets to add the stock in her display. When a buyer comes, she asks whether eggs are still available or not.

Utterance 1: Tigane kantun niku thok nggih Bu?

tigane kantun niku tok nih bu

Are these the only eggs left mam?

Utterance 2: Akeh koh teksih niko. Niki, niki kang mriki. ake h koh te ksih ake h niko niki kay mriki

There are many. Come..come here.

Utterance 3: Oh.... Nyuwun sekawan kilo Bu

oh .....nyuwun sakawan kilo bu

Oh ... Four kilograms please, Mam.

Utterance 4: Nggih

ygih

OK

The conversational implicature of the above conversation is promising and commanding. Promising is classified as commissive and commanding is classified as directive based on Searle's classification. The buyer is promising to the shop owner that she wants to buy the good as long as there are enough supply. By producing her utterance Tigane kantun niku thok nggih Bu? The buyer does not merely asking the availability of the good but she also making a promise if the good is enough, she will buy them. After hearing her utterance, the shop owner then makes some assumptions as follows:

1. The buyer is a potential buyer, so if the good is available, the buyer will buy.

2. The shop owner knows exactly that she has enough supply.

Those assumptions lead her to make an implication that the buyer is making promise to buy. Knowing that her buyer wants to buy the good if the supply is enough, the shop owner then make a reply Akeh koh teksih niko. Niki, niki kang mriki. It does not only mean to answer the availability of the goods but also a command for her buyer to buy. After hearing such reply, the buyer then makes some assumptions as follows:

1. The good is available more than she ever wants to buy.

2. She has not heard if the shop owner increases the price which means the price is reasonable.

3. She needs to buy egg for her own goal.

Those assumptions lead her make an implication that the shop owner commands her to buy the good. To ask the availability of the good, both buyer and shop owner use the word kantun and akeh. Kantun means ' something left' and akeh means many.

If the buyer says directly that she will buy the goods provided that the goods is available, she can say, for example, 'I want to buy egg if there is any'. In addition, the similar thing also happens to the seller. To give command to her buyer, she can simply say "OK, the goods is available, then buy them as much as you want". However, the conversation does not show those things. Both buyer and seller use indirect utterances to show their intention. The implicature produced by the buyer is promising and the implicature produced by the seller is commanding. Promising is grouped into commissive and commanding is grouped into directive.

Both buyers and sellers use indirectness in their utterances to show respect each other. The indirectness is realized in high Javanese language variety. The buyer is younger than the seller hence she uses 'krama inggil' - high Javanese language variety- to the seller. So does the seller. Even though she is older than her buyer, she still uses 'krama inggil'. 
Both of them use indirectness in high Javanese variety to show their respect. Once again, indirectness emerges in traditional selling and buying conversation. The emergence of implicature highlights the phenomenon of Cablaka needs to be further defined.

The next conversation which contains conversational implicature shows the indirectness in Banyumasan dialect.

Context: A second buyer comes to the shop after the first buyer left. She knows if if the shop owner has a stock of coconut sugar in her store house which locates behind the shop.

Utterance 1: Mba Endang ajeng piten?

mba $\varepsilon$ nday ajoy pinton

Miss Endang, how much do you want?

Utterance 2: Kalih.

kalih

Two

Utterance 3: Mrika milih

mrika milih

Please choose

Utterance 4: Ngarep?

yarəp

In front?

Utterance 5: Bebas, milih njero ya kena, ngarep ya kena. be bas milih njaro ya kəna narəp ya kəna

It's up to you, whether inside or in font

The buyer says Ngarep which semantically means in front of. Spatially, ngarep means the shop and what she really intends to say is that she wants to choose the good in the store house which is behind the shop. To say it directly, the buyer can simply say that she want to choose the good in the store house. By saying the opposite utterance, the buyer expresses her intention that she makes a request. The buyer is requesting to choose the coconut sugar in the store house because she knows there are plenty of palm sugar with good quality as she wants. By saying Ngarep? she also performs a request to choose the coconut sugar in the store house, which locates behind the shop. Instead of saying to choose the good in the shop (which is in the front location), the buyer implicitly say that she wants to choose the goods in the store house which location is behind the shop.

This conversational implicature is derived from the contextual assumptions as follows.

1. The buyer knows that the shop owner still has stock of the good sh wants in her store house.

2. The buyer knows the location of the store house is behind the shop in which the shop owner usually keeps her stock.

3. The buyer knows that when she comes to the shop, another buyer has just left which means that the good she wants may have been bought by the previous buyer.

Those assumptions lead the shop owner to make a contextual implication that the buyer is requesting to choose the good in her store house. Hence the conversational implicature of this conversation is requesting. The implicature emerges from the utterance Ngarep which means in front. In fact both buyer and shop owner know that the store house is behind the shop not in front. This conversational implicature comes up because of this utterance which means that the implicature is calculable on the basis of conventional meaning together with contextual information. The buyer knows that the store house is behind the shop, instead of saying mburi which means 'behind', she says ngarep which means 'in front'. The conversational implicature of the above conversation is requesting. Requesting is classified as directive based on Searle's classification.

Requesting is considered as a high-cost speech acts, hence to reduce it, the speaker uses indirectness. By using indirectness the speaker tries to soften her utterance to her hearer. Softening her utterance is one characteristic of woman's speech. The indirectness is used to soften an utterance. The existence of indirectness in the conversation above portraits implicature. It is once again shows that Cablaka is not reflected in the conversation.

The below conversation which happens between the shop owner and the shop assistant also depict the indirectness.

Context: The shop assistant is classifying and packing the coconut sugar. She classifies them based on good and bad quality. She asks the shop owner if the coconut sugar from one of her sellers is mostly bad.

Utterance 1: Gendise pak niko lah jarang sing apik nggih Bu. gendise pak niko lah jaray siy apik ngih bu $\mathrm{Mr} \mathrm{X}^{\prime}$ coconut sugar is rarely good, isn't it Mom?

Utterance 2: Wiryo? wiryo Wiryo?

Utterance 3: Enggih eygih Yes

Utterance 4: Lah sing apik kaya wis nggo eceran. 
lah siy apik kaya wis ygo $\varepsilon$ ce ran

The good one has already been sold for retail.

By saying Gendise pak niko lah jarang sing apik nggih $\mathrm{Bu}$, the shop assistant accuses that the coconut sugar seller is not faithful. Her utterance says indirectly that the quality of Mr. X coconut sugar is barely good and perhaps he has sold the good ne to another. This conversational implicature is derived from two contextual assumptions as follows.

1. The shop owner knows exactly that the price of coconut sugar is increasing rapidly at that time.

2. Since the price is increasing rapidly, no wonder some of her unfaithful seller sometimes sells their palm sugar to another in order to get higher price.

3. The shop owner knows that $\mathrm{Mr}$. X is not a faithful seller.

Those assumptions lead the shop owner to make a contextual implication that the shop assistant is accusing that Mr. $\mathrm{X}$ has sold his goods to another shop. The shop owner agrees on her shop assistant' report. Hence she makes an utterance Lah sing apik kaya wis nggo eceran. By saying it, she agrees with her shop assistant.

The conversational implicature of the above conversation is accusing. Accusing is classified as representative based on Searle's classification. If the shop assistant explicitly says that Mr. X sells his good to another shop, she can be said that she reflects Cablaka in her utterance. The shop assistance uses indirectness to accuse her boss's business partner. If she makes a direct accuse, she may be get fired. So she tries to make accuse carefully by not saying it directly. It can be said that the shop assistant. She uses indirect utterance to show her carefulness. She can deliver her message and be careful at the same time. The use of indirectness one again denies Cablaka and this shows that Cablaka is not always reflected in people utterances especially in Banyumas dialect.

The next conversation displays that implicature happens in Banyumasan dialect. The conversational implicature in the next conversation also shows that Cabaka is not always reflected in people's utterances.

Context: A buyer comes to buy coconut sugar. Before she buys, she pays her debt to the shop owner. The shop owner asks her about the condition of her trade.

Utterance 1: Sepi apa rame Mba Endang?

sapi apa rame mba $\varepsilon$ nday

Slack or life Miss Endang?

Utterance 2: Dalem?

dalam

Pardon

Utterance 3: Sepi apa rame?

sapi apa rame

Slack or life?

Utterance 4: Kepripun si nggih?.... Duko lah....

Kapripun si ygih dukolah

Well I don't know what to say...I don't know...

The conversational implicature of the above conversation is keeping a secret. Keeping a secret is classified as representative based on Searle's classification. The buyer tries to keep a secret about the condition of her trade. By saying Kepripun si nggih?... Duko lah buyer does not want to say the real condition of her trade. She does not want to answer the shop owner question due to the fact that she knows her trade is not in a really good condition. If she says that it is good, she still has debt to the shop owner if she says it is bad, she still can buy coconut sugar for her home industry. By relating her utterance with her condition, the conversational implicature reveals, that is keeping a secret. This conversational implicature is derived from the contextual assumptions as follows.

1. Buyer still has debt to the shop owner.

2. Buyer is still able to buy coconut sugar for her home industry which means that she still has money to support her home industry.

From those contextual assumptions, the shop owner then makes a contextual implication that buyer keeps a secret about her trade condition. By saying Kepripun si nggih?... Duko lah buyer expresses her intention to keep a secret. Both kepripun si nggih and duko lah more or less have the same meaning that is uncertainty. Buyer does not want to show her trade real condition to the shop owner, hence she produces utterance which shows uncertainty. This expression is meant to show that she wants to keep a secret.

Trying to keep a secret, buyer produces indirect expression. In the conversation above, indirectness is used to show uncertainty. The speaker feels uncertain on her trade condition so she cannot say directly to her interlocutor. In her effort to show uncertainty, the speaker uses indirect utterance. As it has already been discussed, indirectness is not a part of Cablaka since Cablaka is said to be frankly. Hence to say that Cablaka is the way of speaking of Banyumas people, it needs to be redefined.

The next conversation figures out the conversational implicature in Banyumasan dialect. It happens between husband and wife-the shop owner and her husband.

Conttext: When a coconut sugar seller offers clove to the shop owner, the shop owner must make sure the dryness of the clove. She just buys 'kapulaga-Amomum cardamomumand wild-and the quality is not so good. As a consequence, she gets financial loss. The shop owner husband tries to warn his wife not to tell that story because there are five other 
customers in the shop.

Utterance 1: Cengkeh bu

cajke $h$ bu

Clove mam

Utterance 2: Nek garing gelem, nek ora emoh. Anu wingi ana wong adol kapulaga. Lah jan aku kayane prei dingin, emoh tuku dingin. Anu sekilo dadi setengah kilo.

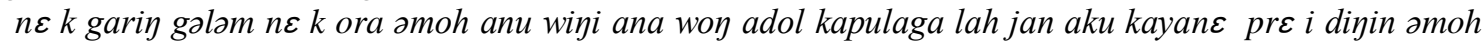
tuku dijin anu səkilo dadi satə’ah kilo

If it is dry, I want to; If it is not, I don't want. Yesterday, there was a seller sold kapulaga. Oh my God, it seems that I am off, I don't want to buy it. It was a kilogram and it becomes half of it.

Utterance 3: Kae ana sms

kae ana sms

There is a sms.

[The shop owner does not continue her story and keeps on serving her customers]

The conversational implicature of the above conversation is forbidding. Forbidding is classified as directives based on Searle's classification. The shop owner husband forbids his wife to continue her complaint. He forbids his wife continuing her complaint because he knows that among their customers who are in the shop at that time, is a relatives of the one who sold Amomum cardamomumand wild which caused them financial loss. After hearing her husband utterance, that is Kae ana sms, the shop owner then makes some contextual assumptions as follows.

1. Shop owner know exactly her husband characteristic, that he seldom expresses something directly.

2. Shop owner does not hear the ring tone of her cell phone that indicates there is a message.

3. Shop owner realizes that there is one relatives of Amonum cardamomumand wild' wild seller among her customers.

Those contextual assumptions then lead her to make a contextual implication that her husband forbids her continuing her complain. Shop owner husband in fact can say directly to his wife not to continue talking about their financial loss due to their purchase. Since he does not say it directly, he makes an indirect expression to forbid his wife. The indirect utterance produced by the shop owner husband is meant to protect both the shop owner face and one of their customer's faces. Face is the image that a person protects in their social contact with other. The shop owner husband tries to protect his face by showing his forbid in indirectness. He also tries not to threat one of his customer's faces who is also the relative of those who sells Amonum cardamomumand wild that makes them suffer from financial loss. The use of indirectness in the conversation above shows that implicature is applied in this conversation and it means that there is once more evidence that Cablaka is not absolutely realized.

Based on the linguistic evidence, that is, the conversational implicature depicted by each conversation, I state that Cablaka as the way of speak of Banyumas people need to be redefined. In spite of the characteristic of Banyumas people which tend to speak frankly, the evidence clearly show us the contrary. The emergence of conversational implicature in Banyumasan dialect positively give us evidence that Banyumas people is not totally frankly or in a simple way it is not totally explicature.

\section{CONCLUSION}

Based on the discussion, it can be inferred that there are some consideration in which people use indirectness. The indirectness is used for disagreeing, promising, commanding, requesting, accusing, keeping a secret, and forbidding. The functions of the indirectness are to show politeness, to show respect, to soften utterance, to show carefulness, to show uncertainty and to keep face. Banyumas people still use those considerations in their way of speaking. People still consider to whom they speak to, in what occasion the speech takes place and to what extent the speech is intended to. They still give respect to other people or their interlocutors so they try not to threaten their interlocutor 'face'. Goffman in Rankema (1994, p. 13) defines face as the image that a person protects in his social contact with other. Considering their interlocutors' face is also the reason why Banyumas people still use indirectness.

Those considerations which have been stated above highlight the use of indirectness in Banyumasan dialect. In a simple way, it can be said that indirectness reflects the conversational implicture. The linguistic evidence, that is, the conversational implicature becomes the base to declare that Banyumasan dialect 'Cablaka' is not totally explicature.

\section{REFERENCES}

[1] Carston, Robyn. (2002). Thought and Utterances: The Pragmatics of Explicit Communication. Oxford: Blackwell Publishing.

[2] Chambers, J.K. \& Peter Trudgill. (1994). Dialectology. Great Britain: Cambridge University Press.

[3] Creswell, John W. (1994). Research Design: Qualitative \& Quantitative Approaches. London: SAGE Publications.

[4] Eggins, Suzzane dan Diana Slade. (1997). Analyzing Casual Conversation. London: CASSELL.

[5] Grice, H.P. (1975). Logic and Conversation. In Cole, P. et al. Syntax and Semantics: Volume 3: Speech Arts. Elsevier: 41-58.

[6] Hammersley, M. (1992). What's Wrong with Ethnography? Methodological Explorations. London: Routledge.

[7] Halliday, M.A.K. dan Ruqaiya Hasan. (1989). Language, Context and Text: Aspect of Language in Social-Semiotic Perspective. Victoria: Deakin University. 
[8] Halliday, M.A.K. (1994). Spoken and Written Language. Victoria: Deakin University.

[9] Herusatoto, Budiono. (2008). Banyumas: Sejarah, Budaya, Bahasa dan Watak. Yogyakarta: PT LkiS Pelangi Aksara Yogyakarta.

[10] Koentjaraningrat. (1984). Kebudayaan Jawa. Jakarta: Balai Pustaka.

[11] Levinson. (1983). Pragmatics. Cambridge: Cambridge University Press.

[12] Mey, Jacob L. (1994). Pragmatics: An Introduction. Oxford: Oxford University Press.

[13] Ogloblin, Alexander K. (2005). Javanese. In Alexander Adelaar and Nikolaus P. Himmelmann (eds). The Austronesian Languages of Asia and Madagascar. New York: Routledge, 590-615.

[14] Rankema, Jan. (1993). Discourse Studies: An Introductory Textbook. Amsterdam: John Benjamin Publishing Company.

[15] Searle, J.R. (1969). Speech Acts. Cambridge: Cambridge University Press.

[16] Sperber, Dan \& Deidre Wilson. (1986). Relevance: Communication and Cognition. Oxford: Basil Blackwel.

[17] Ventola, E.M. (1979). The Structure of Casual Conversation. Journal of Pragmatics 3: 267-298.

[18] Wedhawati et. al. (2006). Tata Bahasa Jawa Mutakhir. Yogyakarta: Penerbit Kanisius.

Chusni Hadiati was born in Banyumas, Central-Java, Indonesia on May $8^{\text {th }} 1980$. Hadiati completed her under graduate degree in Diponegoro University, Semarang, Indonesia in 2002. Hadiati also gained her post-graduate degree in the same university in 2007. Hadiati's major interest is linguistics.

She is a lecturer in English Department of Department of Humanities, Faculty of Social and Political Sciences in Jenderal Soedirman University in Purwokerto, Central-Java, Indonesia. She is working on pragmatic approach in traditional selling and buying in Banyumasan as the topic of her dissertation. 